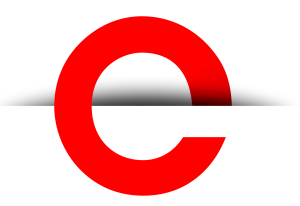

U T S

e PRES S
PORTAL Journal of

Multidisciplinary International Studies

Vol. 17, No. $1 / 2$

Jan 2021
CULTURAL WORK

\section{La Vaca}

\section{K. Angelique Dwyer}

Corresponding author: Associate Professor K. Angelique Dwyer, Associate Professor of Spanish, Chair of Latin American, Latinx, and Caribbean Studies, Gustavus Adolphus College, Department of Modern Languages, Literatures and Cultures, 800 West College Avenue, St. Peter, MN 56082, United States. adwyerdgustavus.edu

DOI: http://dx.doi.org/10.5130/pjmis.v17i1-2.7257

Article History: Received 19/06/2020; Accepted 11/11/2020; Published 28/01/2021

\section{Abstract}

This creative non-fiction piece written in Spanglish is called 'La Vaca.' The overarching themes of this story are birth, motherhood, siblings and the creative force in a nonconventional American family raised in Mexico. The narrative voice in this piece provides a unique perspective broadening dialogue(s) on Mexican American identity.

\section{Keywords}

\section{Gringos; Motherhood; Feminism; Siblings; New masculinities; Coatlicue}

\author{
Every day \\ Igrow. \\ Iam mother nature. \\ I am mother.
}

Una mañana, bien tempranito-I remember it well, because we ended up getting the day off from school-nos despertaron los gemidos de la vaca. It was 'dark morning' as el Piti called it when he was little. We could hear the cow moaning, announcing the arrival of her calf. Piti and I hurried to put our uniforms on for school and ran down to the barn. Sebas and his dad were already there working the field. It was one of those daybreaks donde Coatlicue usa el cielo de canvas para pintar con colores pastel. The sun wasn't fully awake yet either, but its warmth and hope were well received by my mom and me who stood side by side in anticipation of the calf's arrival. El becerro nació y la vaca lo lamía, orgullosa. We all stood 
there watching the perfect picture of motherhood: la vaca con su becerrito. After only a couple minutes, the calf stood itself up, como tripié and began to nurse.

Lo que más me asombró sobre mi primera experiencia de parto—what a transition, right?-was that my body instinctively knew exactly what to do. Nadie me dijo qué hacer, there was no: 'PUSH!' continually yelled at me, like in the movies. It was my own body that naturally began to tremble, and tighten, and flow. Fui de un gemir bajito a un staccato, terminando en un altissimo, similar al de aquella vaca.

Y fui yo quien le dije a las enfermeras que sentía venir a la niña.

- 'Are you having a contraction?'The nurse asked me.

'Duh...' is what I wanted to say as I huddled over, but instead just said:

- 'She's crowning,' which led the nurse and doula to run and get a doctor. Eran las cuatro de la mañana cuando llegamos al hospital. It was a full moon y todos los cuartos estaban ocupados. So, I started off in a small waiting room and then was moved to a birthing room with a tub, where I completed my labor, as suggested by my doula. It was the perfect labor team: el caribeñito, our doula and me. It was dark, quiet and the water was warm. Each contraction got stronger and moved me to my core. Birthing, I thought, is something that connects women throughout the ages, and I asked for their strength. I knew my mother, grandmother and great grandmother all gave birth many times. I mentally pictured the photo my mom has of our 4 female generations, and I asked for their strength as I brought a $5^{\text {th }}$ female to join us and continue the legacy.

La doctora entró and tried to fish me out of the tub because of hospital regulations.

- 'Common, we need to get you to the birthing table,' she announced, thinking there were still a couple hours of pushing left. So, I got on my hands and knees in the tub, con la niña coronando.

- ¿La ves?' le pregunté a su papá who tried to peek under the water. But, since the doula nor the staff spoke Spanish, they simply pulled me up out of the water. Hasta hoy día agradezco con todo mi fervor que nunca subí la pierna para salirme de la tina, because just then, my bungy-jumping-like, Olympian-divinglike, ever-so-rebellious-like, spirited girl sprung out, being caught by six hands in midair. Y así nació mi niña.

\section{As I look at my child \\ Thoughts of my mother \\ Echo in my mind. \\ 'Precious girl,' \\ Whispered into my sleepy ear. \\ 'Niña linda' le digo a la mía.}

I remember my mom holding me in her arms while we both showered. Bonding skin to skin, woman and girl. That special human connection. Can there be anything more pure? I saw a film a couple years ago, una guatemalteca, de una madre quiché que baña a su hija que está embarazada: tres generaciones cuidándose entre sí. Women caring for women, past and present.

Way before the slogan 'walk in a woman's shoes' could have had any meaning for my brother, he wore them home. En aquellos tiempos teníamos una combi blanca alemana con orange and black checkered curtains and upholstery. We were driving home late on a Sunday evening after a Primera Comunión in Poncitlán. Back in those days taking the brecha was the quickest way to get home, but it was also the darkest. No había postes de luz ni nada por el estilo en esos terrenos, so when the van broke down and dad couldn't fix it no había de otra más que irnos caminando hasta la casa. The first half hour was like watching an oral reenactment of my parents performing the Clash's 'Should I Stay or Should I Go.' Shortly thereafter, it was established that... ámonos, was the verdict. So, we all just walked in the pitch darkness, bien catrines: peinados y perfumados, we walked home in our best shoes with sore feet del bailongo que ya nos habíamos echado. La señora Linda, a tall and attractive lady, had on her best gray 80's heel pumps. After managing to 
walk half of the way up hill through the dirt and gravel, she needed to stop. And just like that, Piti took off his size 10 sneakers and wore my mom's heels all the way home. Little did I know then, as we reached home in the bliss of daybreak, the importance of raising men who understand women.

Years later, when I birthed a second time, my fish boy came to me. The sweetest boy a man could be, con el corazón tierno y la disposición abierta. Named after a rebel and a city, but answers to dogs and flows to the rhythm of the sea.

As I did some freelance curricular work teaching Spanish for Veterinarians, I searched for images of birthing cows, and remembered that day. No hay mañana como esa, ¡no la hay! Y como dice la criada de Gone with the Wind: 'The best times are when babies are born,' no importa si eran mis gatitos, los cachorritos de la Vicky, el becerrito de aquella mañana, when I find birds in a nearby nest, or, best of all, when it's my own nest full of niños, sobrinos y cuentos. 